\title{
Tenure in a Chilly Climate
}

\section{Anonymous and Anonymous*}

In this article we discuss the emo-

tional and structural dimensions of seeking tenure in a chilly climate ${ }^{1}$ and describe and analyze the devaluation and hostility junior women faculty experience working in that climate. We write as two women who have been through difficult tenure cases (one of us succeeded, one of us did not). Happily, we both have moved on to other institutions as tenured faculty. We have both experienced the profession and our own tenure processes as profoundly gendered. Despite the obsessing about tenure that threatens to consume so many conversations among junior faculty, both of us knew very little about what it was like to live through a difficult tenure case. We have been struck by how submerged the stories are. We have known colleagues for years before learning that they were denied tenure at their first job. We have heard snippets of stories about earlier Department of Labor complaints or lawsuits filed against our own departments but have rarely heard complete accounts. We relay parts of our stories because sharing them with each other has helped us to understand our own situations and move on, talking with others who had been through the experience while we were going through it was uniquely helpful, and, frankly, we would have liked to have read others' stories at the time. ${ }^{2}$ The similarities between our two stories and others we have learned of suggest that our cases are not merely idiosyncratic.

We also wish to supplement the written advice to assistant professors on the tenure process (Becker 1986; Boice 1992; Leap 1995; Limbert 1995; Toth 1997; Whicker, Kronenfeld, and Strickland 1993; Wuffle 1993). We both benefited from the advice and support we received from men and women at our home insti- tutions, within the discipline, and elsewhere. ${ }^{3}$ Yet, advisers seldom discuss what it feels like to go through a difficult tenure case and how to cope. Sometimes, even advice that recognizes the gendered nature of the process leaves its recipient with the impression that success is solely within her control if only she could learn the magic formula. However good the advice, and well meaning the adviser, following the advice will not guarantee success in all situations, no matter how much the junior faculty woman hopes that if she is just a good girl, a good scholar, and a good teacher, all will be well. One of the most difficult tasks of the junior faculty member, which is compounded for the feminist woman professor, is objectively assessing the situation. Some people whose work is excellent and who are having no difficulty will agonize about whether they are liked, or whether the subject matter or topic of their work will damn them. Others who publish little, or whose work is not strong, will refuse to hear advice and warnings and focus instead on the unreasonableness of publication expectations, the prejudice of senior colleagues against them, and their impossible teaching and service loads. ${ }^{4}$ Sometimes, however, doing everything required is simply not enough. Even good departments may occasionally do things to create a chilly climate. With all this in mind, we offer our thoughts to those people who are experiencing hostility and devaluation, as well as those who want to help create a positive climate for everyone.

\section{Shame as Silencing}

One of the worst effects of being in a hostile department, or perhaps just going through a difficult tenure process in any department, ${ }^{5}$ is that the faculty member develops a profound sense of shame-she comes to believe that she deserves to be treated badly. It must be her fault. She thinks: "If only I had published more, gotten better teaching reviews, voted differently, had more colleagues over for dinner, not worn jeans, used more makeup. ..." Although it means ultimately blaming oneself for everything, this construct has the effect of leaving intact the perception of control. Identifying the "careless" behavior of victims leaves observers feeling different and therefore immune-psychologically distancing themselves from their own vulnerability. Denial of tenure carries an enormous stigma: the assistant professor's closest colleagues think her work is inadequate and no longer want to continue to work with her. Why would anyone want to broadcast such a personal and professional rejection? To do so only serves to diminish one's reputation. Many people refuse to see themselves as victims of discrimination precisely because "victim" is such a degraded status (Bumiller 1987).

The time has come to break the silence and address questions of climate rather than focusing only on questions of discrimination in hiring and promotion (Baker and Meyer 1993; The Chilly Climate Collective 1995; Hall and Sandler 1986; Hesli and Burrell 1995). Silence about a poor workplace environment reinforces the mistaken belief that all is well in the postfeminist era and equal employment opportunity efforts are unnecessary or that things are steadily getting better. ${ }^{6}$ Our stories about previous workplaces and tenure battles are also part of the story of how gender and gender oppression are reproduced in daily life (Kenney 1996a; Schultz 1998).

We think some of our experiences 
are likely to be common to women and men of color. Subfield, institution, personality, and other factors have also shaped our experience. While we criticize our former workplaces and the profession as a whole, we want to note that we could not still be in the profession had we not found generous colleagues, both within and outside our particular universities, and at our present ones. Both men and women in the profession have encouraged and supported us over the years. It is precisely because we have enjoyed collegiality despite methodological and substantive differences that we want to criticize its too frequent absence. $^{7}$

\section{The Double Bind}

Both men and women in the profession have encouraged and supported us over the years. It is precisely because we have enjoyed collegiality despite methodological and substantive differences that we want to criticize its too frequent absence.
One of the most characteristic and ubiquitous features of the world as experienced by oppressed people is the double bind-situations in which options are reduced to a very few and all of them expose one to penalty, censure, or deprivation (Frye 1983, 2). ${ }^{8}$ For example, it might seem to be simple common sense not to speak up concerning divisive issues in the department, which can range from hiring to placement of the coffee machine. At the same time, as feminists, we do not believe that our jobs are worth having at any price, or that power is to be hoarded to expend only at some future day. In fact, for anyone likely to be denied tenure, the only chance to speak up for what she cares about may be as a junior person. ${ }^{9}$ Remaining silent carries other risks. A quiet person has no presence that can shape senior faculty's image of who she is. Mousy women cannot present themselves as powerful, dynamic scholars capable of leading their disciplines. Cultivating the image of a strong, independent, productive scholar is particularly problematic for women men of color because stereorun rampant when there are In our experience, those stereotypes for women are based on images of compliant, white, straight women; women of color face more confounding double binds (Greene 1997; Russell 1997)..$^{10}$

Compliant behavior would include doing the service requested, while not doing so much that it makes writing impossible. That fine line is difficult to walk. In many departments, assistant professors are volunteered for service. They do not always know what assignments to avoid and often find themselves, for instance, participating in hiring, only to find that when they take their new responsibility seriously they have offended senior colleagues by taking up the cause of a potential hire other faculty dislike. Junior faculty can also be volunteered for thankless tasks destined to keep them from following or developing research plans. Refusing service out of a concern that it might lead to nothing but trouble is a dodgy proposition. Colleagues can easily remember refusals of service, making it easier to perceive that assistant professor as "difficult."

Senior colleagues often see women as feminine-sweet, compliant, and nurturing-and, consequently, may not hesitate to burden women faculty with excessive service assignments of the kind that academics do not value and associate with nurturing children-such as director of undergraduate studies (Toth 1997, 98-99). Women might also have high demands for student advising, whether or not the department requires this, because women students will seek them out with accounts of rape, domestic violence, sexual harassment, and discrimination, or merely because students see them as role models and want to spend time with them. ${ }^{11}$ Junior women might also teach in areas with heavy undergraduate demand (Kolodny 1993, 19-22). If the junior woman acquiesces in departmental demands for service and teaching, senior colleagues might really believe they like her; they might wonder why more professional women are not like her. However, when it comes time to make decisions about tenure, these same senior faculty are as likely to find, sadly, that she is just not "professional" enough. Women understood to be feminine cannot be professional, virtually by definition. Going along with demands from senior colleagues might seem a good idea, but feminine behavior by women is seldom professionally rewarded.

Conversely, a competing stereotype of women in professional settings is that they are very "professional": they publish, they speak up, and they do not seem to be especially nurturing. These women seem to be masculine, somehow, and do not satisfy senior colleagues' expectations of what a woman should be. Again, regardless of research records or actual behavior, departments may deny these women tenure because they are "difficult" and no one would want to have them as colleagues. Closely related to the double bind, then, is the double standard. The same behavior that earns men the label of "star" or "dedicated scholar" earns women the label of "bitch" (Chamallas 1990; Disch and Kane 1996, 28182). ${ }^{12}$

In our experience, few people want to think of themselves as hostile to women ${ }^{13}$ and have a variety of strategies to exonerate themselves. They find a "good girl," one they like, and a "bad girl," one they do not. Who gets assigned which role may have little to do with how the women actually behave. Sorting women in this way permits senior faculty to reassure themselves that they do not actually dislike women, just the one "bad" woman. The oc- 
cupants of the good girl role may change, as people need a different stick (so to speak) to beat the bad girl. But the girls will generally be judged as a separate species of colleague. Departments may hire women assistant professors and deny each one tenure in sequence. Pigeonholing the new hires allows a department to individualize the problem, leaving no pattern to be discovered except that the women hired have all turned out to be, regrettably, not tenurable.

Even following the advice to find a mentor can create a double bind, as mentoring may be interpreted differently for men and women. Women working with men mentors may be perceived as having a sexual relationship (Chamallas 1994).

When men write with others, it can be taken as evidence of desirable collaboration. When women are joint authors, they may be characterized as coasting on the work of others, be they graduate students or senior scholars (Fisher et al. 1998, 846-47). Furthermore, aligning oneself with a senior scholar in a department often means acquiring his enemies and political disabilities (Limbert 1995).

Individuals need to take responsibility for their choices and the amount of service they do, but departments and institutions also need to encourage junior scholars' development and to integrate them into the profession (Bateson 1989). What if, rather than evaluating individual women as successes or failures, we evaluated individual departments? What if those concerned with the status of women in the profession looked beyond hiring records and numbers and examined whether departments created an environment where women could flourish?

\section{Examples of Hostility and Devaluation}

We would like to offer from our experiences a handful of examples of hostility and devaluation. Devaluation may be overcome or somewhat mitigated through aggressive selfpromotion and educating well-intentioned allies over time. Hostility is more dangerous and difficult to counteract. To begin with, it is a sign that no amount of success or reeducation will ever permit the woman junior faculty member to earn approval. Further, it indicates a climate where she cannot flourish. Assistant professors are not always good at recognizing devaluation and hostility as real problems because they can take too seriously the idea that if they do their job well they will get tenure or easily move elsewhere. Women junior faculty should see personal hostility as a red flag no matter how successful and "safe" they believe themselves to be. We agree with Dalton's advice: "Never underestimate the danger you are in" $(1988,7)$. Thinking one can overcome it with publications, good teaching evaluations, and, that last ditch effort of no hope, service to the department or the university is a mistake. Thinking one can overcome it by simply being American-style friendly may also be delusional. If hostility cannot be overcome, take seriously its costs. Even with tenure and supportive friendships, a hostile environment takes its toll.

Assistant professors may tell themselves that, in these tight budget times when a department is not guaranteed a replacement, a department would not dare deny tenure to someone who has a plausible case. They might also think that departments would not vote against, nor university administrators turn down, a high-profile woman with a strong research record. They would be wrong. Some political science departments seem prepared to pay any price to have their way.

The first sign of trouble is silence-no hostile comments, just a reluctance to speak to the junior colleague. An assistant professor can easily think that because she does not have hostile encounters in the halls that department members must think she is acceptable and that everyone is just doing their job rather than chatting. Such reticence is a sign of trouble, not indifference.

Other, more easily recognizable signs of hostility that we experienced, and that tenure candidates cannot overcome through professionalism, are summarized below.

1. When I arrived to begin my job, two colleagues refused to shake my outstretched hand. This affront

was a sign that they not only voted against hiring me but had no intention of extending me common courtesy.

2. "Get back in your hole." Early in my career, I decided to make a

conscious effort to join in hallway banter after men friends told me one of my problems was that senior people did not have a sense of who I was. After I attempted to join one casual conversation, a senior colleague ordered me back into my office with the comment above. ${ }^{14}$

3. "Your publications are fine, your teaching is fine, there is just something that emanates from your door." This comment came from a senior colleague at the beginning of my tenure review. How does one change one's "emanations?"

4. Other faculty members' wives began to shun me at social gatherings, even though I had no previous quarrels with them. Just when I had persuaded myself that two-career couples do not have dinner parties in the $1990 \mathrm{~s}$, and that I was not really being ostracized even though I had not been invited to lunch with colleagues, let alone to their homes, in six years, the $\mathrm{ABD}$ who had been in the department three months showed up at the holiday party and knew the names of and was recognized by the chair and host's animals and children.

5. "We need a big data gangbang." This was a colleague's way of saying that "more research is needed." Political science departments are very male and senior political scientists in many departments are very likely to be almost exclusively men (Sarkees and McGlen $1992,48)$. One result of this male 


\section{Descriptions of Political Science Ph.D. Programs Sought}

The Pew Charitable Trusts have awarded a $\$ 515,000$ grant to the Center for Instructional Development and Research and the Graduate School at the University of Washington to develop an extensive nationwide inventory of initiatives to reform doctoral education. The "Reenvisioning the Ph.D." project intends to include any projects in political science that call for modification in the requirements to obtain a Ph.D., and also programs designed to change the way doctoral students are prepared to become college and university professors. Jody D. Nyquist, director of the Center and assistant dean, and her research team are reviewing the literature on the subject of doctoral education and interviewing representatives of industries, businesses, and government agencies that hire doctoral graduates, as well as individuals in key educational institutions and organizations. Nyquist has already met with Sheilah Mann, the American Political Science Association's Director of Educational and Professional Affairs, discuss changes taking place in the training of doctoral students.

To ensure that political science Ph.D. programs are represented in the data and in the discussions, political scientists are encouraged to contact the researchers at re-envision@cidr.washington.edu with responses to the following questions:

- Have the requirements of the Ph.D. changed in your departments, or are changes anticipated?

- Have you or your colleagues produced materials, praise, or criticism related to the Ph.D.?

- Are there examples of current and promising practices or programs that political science departments have implemented?

Although it is widely considered the best in the world, American graduate education has come under attack in recent years from critics demanding a profound rethinking of its traditional emphases and practices. One major complaint is that the traditional doctorate is too exclusively concerned with scholarly research. This narrow focus leaves students inadequately prepared for the other responsibilities of faculty life and unprepared for the growing percentage of job opportunities in business, industry, and government.

Ellen Wert, an officer for Pew's Education Program, said that this grant is linked to a number of initiatives the Trusts are currently funding. Increasing concerns nationally about the quality of undergraduate education have intensified the demand for such reform in the area of gradvate education. Wert points out that although reshaping the academic profession requires intervention at many points in the faculty career, a critical point of intervention is at the beginning of the faculty training.

An advisory committee composed of 8 to 10 people respresenting the many segments of society who care about the Ph.D. will meet once next spring and again next fall to review the progress of the research and contribute to it. This group will also commission papers describing promising ideas and avenues to pursue based on the information collected and analyzed. The culmination of the project is a conference with a wide representation of interested persons to be held at the University of Washington in the spring of 2000 . Further information can be found online at http://depts.washington.edu/envision/ or by calling (206) 543-6588. dominance is that what is considered acceptable in terms of the metaphors one can use may more closely resemble the high school boy's locker room than what one might expect at institutions of higher learning. Even if the jokes and metaphors are not deliberate tests of the new woman (as they often are: Is she going to be [that word again] "difficult"?), they cast her as outside the group and emphasize her difference (Kanter 1977, 222). They reveal (intentionally or unintentionally) how the speaker thinks-what he thinks about who belongs, about the role of women, and about the discipline. Men often report fearing "touchy" or "oversensitive" women because such women "misunderstand" the true intention of the speaker. Men cannot then express themselves freely. Their speech is censored. Our experience suggests that such "gaffes" are not always a failure to match speech with thought but, on the contrary, reveal what the speaker really thinks.

I recall accompanying a senior colleague to the airport to pick up a visiting speaker. The two had not met, and had not yet settled on sports or computer talk in order to bond. Instead, they both shared the (clearly oft-repeated and taken for granted as shared) joke: "You know you are getting older when you feel like hitting on your students' mothers instead of your students." Then they looked at me and fell silent. I was told of another colleague who told a graduate class he was glad there were no women in the class because their absence freed him to tell sexist jokes. One colleague showed me around his house in what I thought was a pleasant enough experience. When we came back outside, he turned to my husband and said, "I had your wife in my bedroom." Such comments communicate that women do not belong in a political science departmentor that they have a purpose other than doing political science. Such comments are also oblique threats: "You are not safe with me; I can take you at any time; and I can say whatever I like about you, even to your husband."

6. "Is your work really political 
'science'?" We both found our difficulties to be the result of a complex mixture of hostility to women scholars, feminist scholarship ${ }^{15}$ comparative work, nonquantitative work, and work in the subfield of public law. At a time when many scholars and administrators are promoting and praising interdisciplinary work, many political scientists are fiercely policing the boundaries of the discipline. Hostile departments define the discipline narrowly. There is, apparently, some essence of political science that senior people in a department can recognize and junior scholars can only hope to capture. Crossing the boundaries of some disciplines, like economics, is rewarded but crossing into others, like law, history, or anthropology, is punished.

7. "You are proof the system works." A senior and influential colleague offered this assessment after the dean recommended that I be tenured. This comment, unlike the others, is not malevolently directed at an individual. It does, however, seek to disable one who has seen all the ways in which the system does not work for her from drawing broader conclusions about patterns. ${ }^{16}$ One's survival, or triumph in a difficult fight that most male colleagues did not have to endure can be interpreted by some as evidence that the system can right itself; for others, the patterns revealed show the system itself to be rotten. When I reported the above comment to a friend, she characterized it as akin to asking the innocent prisoner who was strapped in the electric chair and received a last-minute reprieve whether he did indeed agree that our criminal justice system is fair.

\section{Standards}

Standards for tenure are notoriously unclear. This vagueness takes many forms. Which journals
In the Profession

\section{Faculty Salaries Up, But Not on Par with Early 1970s}

According to a recent study published by the National Center for Education Statistics, the average salary for post-secondary faculty members has increased-relative to inflation-since the mid-1980s. Recent salary increases, however, failed to make up for the losses experienced in the 1970s. The average salaries of full, associate, and assistant professors remained below those in 1970.

\section{Average Salary of Full-Time Instructional Faculty, In Consant 1996 Dollars, 1970-95}

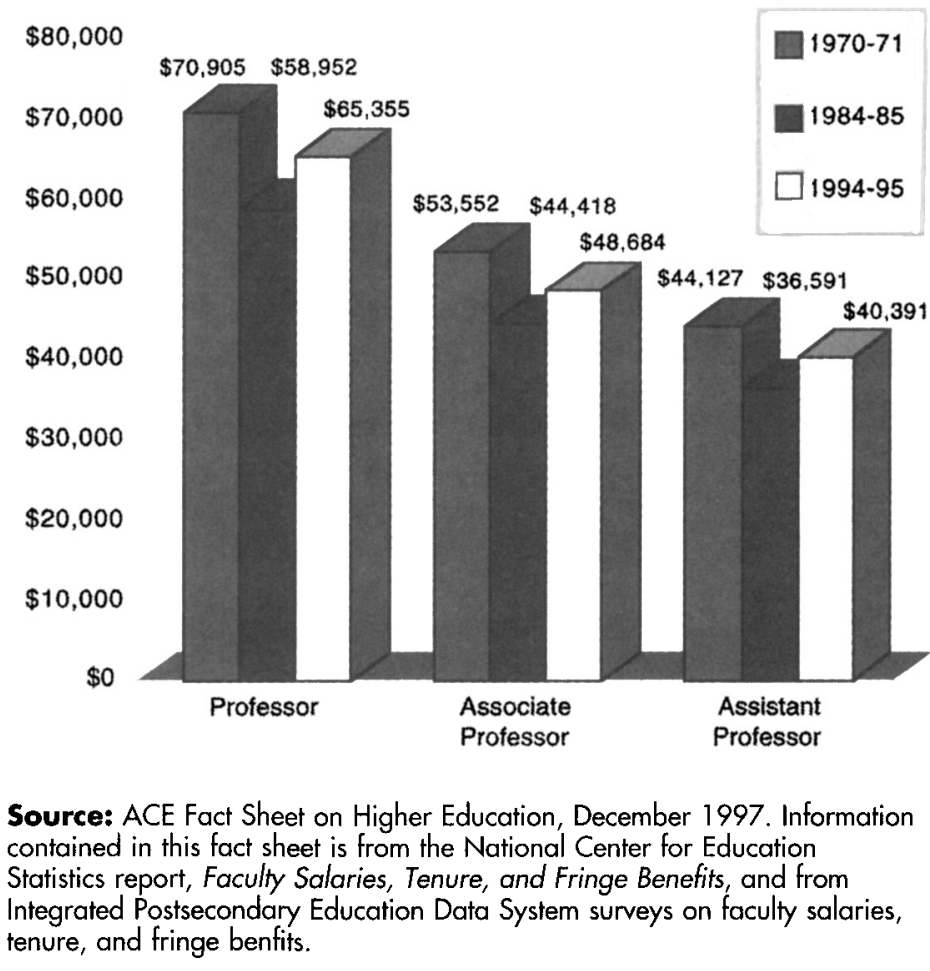

The chart below-featured in the American Council of Education newsletter, Higher Education and National Affairs-illustrates this phenomenon.

For the salary trend among political science faculty at different ranks, see the annual APSA publication, APSA Survey of Political Science Departments. APSA has been collecting these data since 1971. The report for the 1997-98 academic year is now available. For information contact the APSA publications office at (202) 4832512.

\section{What Students Expect to Major in}

What are college freshman planning to major in? Political science is a good option. In the recently released Freshman Survey by the Higher Education Research Institute, $2 \%$ of the total respondents selected political science as their major of choice. This figure represents the $2.1 \%$ of women and $1.8 \%$ of men who noted their major as political science. As a whole, social science majors accounted for $8.4 \%$ of the total respondents, with only psychology, at $4.1 \%$, ranking above political science.

The survey, now in its thirty-third year, is intended to provide a look at how the attitudes and aspirations of college freshman have changed over time. This year's report is based on the responses of $275,811 \mathrm{stu}$ dents at 469 two- and four-year institutions. 
"count?" Just as I had an article accepted into what some regarded as the fourth top political science journal, I was told for the first time (six months before my tenure review) that I had to publish in one of the top three journals to be promoted. Courts most often defer to departmental assessments unless there is strong evidence of intentional discrimination and/or severe procedural irregularities (Leap 1995). We found the vagueness less troubling than the glaring inconsistency with which individuals and departments applied the standards (Kolodny 1993, 22). The double standard reemerges. A junior faculty man's coauthored work (with his adviser or not) is evidence of the high value the senior scholar places on the junior scholar's contribution; a woman's coauthored article constitutes evidence she cannot work independently. For one person, placement in a particular journal is conclusive evidence of excellence, for another, placement in the same journal is meaningless because the topic or the work is disliked by the reader.

Departments usually request evaluations from outside reviewers. Departments can read external letters using different presumptions. Derrick Bell has written what he calls the "rules of racial standing"-that is, rules people in authority invoke when determining whose opinion counts (Bell 1993, 109-26). We believe that there are corollary rules for counting or discounting opinions concerning academic job performance for women, particularly feminists. Women's positive reviews of our work counted for little because women, of course, celebrate and support each other (that nurturing thing again) regardless of the quality of our work (Committee on the Status of Women 1992, 550; Dalton $1988,7)$. On the other hand, women who were willing to dismiss our work, no matter whether their substantive specialties were related, enjoyed what Bell has called "enhanced standing" (Bell 1993, 114). In the same vein, the presence of one or more women on the faculty voting on tenure is supposed to be clear and convincing evidence that there could not have been any discrimination.

Taken together, these forms of hostility are indications not that a junior scholar should "tough it out," but that she should seriously consider the possibility that winning approval may be outside of her control. Both of us wish we had moved on earlier. Still, getting another job is not easy and relocating partners and children is difficult. Moreover, no happy, trouble-free, nonsexist paradise exists. And, why should the victim pay the price of moving from a hostile environment? Should she not stay and fight for her rights, and for those other women who will follow her? Moving may be an individual solution, but it does not resolve the systemic problem. Even if the value of being in a particular location is worth enduring exclusion, lower pay, fewer benefits, having her students punished and other students openly discouraged from working with her, we both think that even the strongest and most selfsufficient scholar can be stifled by being surrounded by those who do not value her (Mathews 1992). Now that we have colleagues who listen when we speak at meetings, who see us as accomplished scholars and good teachers, and who value our service, we know what a huge difference being valued makes to both our spirits and our productivity.

\section{Marathons}

The length of time the tenure process takes in a contested case is inhumane. A department may ask a candidate to prepare her file, including a statement of research and teaching, in the late spring of her fifth year so that the administration may reach its decision in the spring of the sixth year. If the case is contested-that is, if the candidate objects to getting fired-each step of the process can be a cliffhanger. Meanwhile, the candidate is expected to carry on as if nothing is happening. If the department tries to fire her at the mid-career review, the whole thing can take years or more, turning stomach aches to ulcers. And if she gets a two-year extension, the process starts again.
Knowing that this time is "difficult" or that one is "under stress" does not prepare one psychologically for the marathon. If one is in a department where senior people speak to junior people, it is considered bad taste to actually refer to the tenure review in social encounters. When the associate dean or a tenure committee member would call on a Saturday morning and my heart would stop beating, certain that some momentous news was coming, I tried to remain calm as the caller asked for an address or a ride to the basketball game. In situations like this, testiness as one tries to regularize one's heartbeat is not appreciated and may constitute further evidence that one is hysterical, neurotic, worried, and, therefore, undeserving of promotion.

\section{Surviving}

How does one get through it? ${ }^{17}$ We both had a tenacious commitment to reading feminist detective novels. Violent escapist fantasies are therapeutic. Terminator 2 is a great movie, and Linda Hamilton is a great role model. (My mystery book group, however, recommended that I not have a series of "how to" books for mystery writers lying around during the most stressful parts of the process. Books on poisons, knives, and guns would not encourage the maintenance of a positive mental attitude.) Perhaps even more therapeutic than the violence were the cowboy-like narratives of lone heroines fighting for survival in a hostile world, and, most importantly, emerging triumphant (Sterett 1994).

People who themselves had been through a difficult tenure process called us and had long, helpful conversations. One friend, who had successfully sued his institution, relayed the symptomology of fighting a tenure case-reminiscent of the cancer warning signs people used to affix to their medicine cabinets. As I was walking down the street questioning my own worth, a Darth Vader-like voice spoke the words of my friend: "You will be plagued with selfdoubt." I thought to myself, "Oh, now I am being plagued with self- 
doubt," and moved on. He also helpfully pointed out that the best revenge is to live a good life. Friends and colleagues from other universities expressed concern and support. When my department turned me down for tenure, my partner bought two pounds of M\&Ms (peanut and plain) and a bottle of rather good red wine. They were lined up for my choosing on the dining room table when I came home from teaching my evening class immediately after receiving the decision.

Both of us found that doing something that had nothing to do with academics was also very helpful. I played with small children at a battered women's shelter once a week; they liked it and I needed it. Cleaning your utensil drawer is also good. "Retail therapy" worked well for both of us. While all the time knowing that our problems could not be solved by excessive consumerism, binge eating, or drinking, we nonetheless felt compelled to repeatedly test these propositions. Once I knew I was getting turned down during my mid-career review, I bought some special earrings to wear as I at- tended the interminable hearings and meetings I knew were coming. One of my closest friends took me shopping for a set of china, which she generously purchased for me at the very time the departmental deliberations on my tenure case were occurring. While they were debating my fate, we were debating the merits of dinnerware patterns.

\section{Conclusion}

One mistake we often make when trying to understand oppression is focusing on the big incidents (and there are far too many of them) rather than analyzing the seemingly trivial pattern of daily experience. Ostracism and segregation of women in hostile departments, and the profession more generally, is maintained through thousands of small interactions as much as official policies prohibiting women from participating (Schultz 1998). ${ }^{18}$ There are two dangers in dwelling on the oppressiveness of daily interactions. First, in isolation, they seem petty; the complainer seems thin-skinned, hypersensitive, and, well, like a complainer. This fear often leads women working in hostile environments to dismiss their own feelings and experiences. Second, recounting stories has a chilling effect on younger women entering the profession. It is counterproductive to share details about the chilly climate if doing so has the effect of deterring women from joining the profession at all. ${ }^{19}$

We think only by speaking out can we identify common structural features of the chilly climate. Despite experiencing both devaluation and hostility, we still believe the academy can be a good place to work and that it is worth struggling to improve the treatment and status of women within our discipline. Not all departments and institutions are the same. To the extent possible, job candidates should shop around. New Ph.D.s should talk to women who have left a department before accepting a position. They should not discount their own emotional life; and never assume that how people respond to them is within their control. Success, at least in the short run, may have to be measured by increased consciousness and sophistication of analysis, which itself may be a precondition of survival (Bell $1993,125)$.

\section{Notes}

\footnotetext{
* Although we are both quite prepared to be identified as the individuals making these remarks, we write anonymously because we had many supportive male colleagues at our previous institutions and we do not want the behavior we describe attributed to them. Also, we would like the discussion to be about the general phenomenon of the chilly climate. We do not want the discussion to devolve into finger pointing and he said/she said about specific incidents. We also want to thank the many people who read and critiqued this article.

1. Not every department fosters a chilly climate. Some exemplary departments have formal mentoring processes for junior faculty. Others work very hard to be scrupulously fair, and create an environment where everyone, including women and feminists, can thrive.

2. Sheila McIntrye (1995, 211-21) has written a powerful statement explaining why women owe it to themselves to speak the truth about their experiences as part of a process of reawakening the self that has been deadened by the experience of exclusion.

3 . In addition to the sources mentioned in the text, we recommend the following sources filled with helpful advice that recognizes the

gendered nature of the academic workplace: Caplan (1994) for advice to departments, Committee on the Status of Women in the Profession (1992), Kenney (1996b), Lucas (1990a), Ruddick and Daniels (1977), and Toth (1997). In addition, Annis Pratt coordinates the National Women's Studies Association's Academic Discrimination Taskforce and publishes advice columns in Concerns and NWSAction.

4. My experience was that no one wanted to hear that I thought many of my colleagues would vote against me no matter what I did. They would say something to the effect of, "Stop being a ninny. Your book is out, you have a second project, you are a superb teacher, nothing can happen." They particularly did not want to hear me complain about everyday slights, the hostile environment, and the department's prior history of discrimination, about which I was beginning to learn.

5. We do recognize that the department is but one participant in the tenure process. Although one may be "saved" by a dean or a provost, having her department vote against tenure, or the chair recommend against her, can be a devastating experience for the candidate, even if she ultimately wins tenure.
}

6. Hesli and Burrell $(1995,106,110)$ found that the numbers of Ph.D.s granted to women in the Midwest are declining after reaching a high in the mid-1980s, and that men and women differ considerably as to whether they believe the climate in their departments to be chilly. Brintnall $(1992,108)$ quantified the greater attrition rates of women and minorities in graduate school and later in professional careers. Sarkees and McGlen (1992) demonstrated that political science lags considerably behind other disciplines in the percentage of women faculty, despite record numbers of women obtaining Ph.D.s in political science.

7. A topic for another essay is why the good guys (and sometimes we include ourselves here) are so tolerant and let the bad guys get away with acting badly. One reviewer, a leading sociologist of small group behavior who herself experienced a difficult tenure case, offered the following observation: "A hostile environment can be and usually is created by just a few offending senior faculty. But this is sufficient to poison the atmosphere in the department because the hostile behavior is specific, interactional, and intermittent. Other faculty, even the good guys, rarely ac- 
tually take action against the hostile behavior because of its embeddedness in interaction and because of general norms among senior faculty to allow each other substantial behavioral leeway. But when the negative behavior is not actually resisted, it leaves standing a negative evaluation association with the woman that subtly influences people's view of what others think of her, which can affect their own evaluations of her, despite their best intentions."

8 . While we do experience the double bind, we want to acknowledge our own privileged position. We are by no means the most oppressed. Some of the patterns we identify hold for other disadvantaged groups in the profession and wider society, others do not.

9. Toth $(1997,143-44)$ argued for strategic silence; for fighting battles after tenure. We agree that assistant professors should be strategic, should tolerate a certain amount of unpleasantness rather than angrily confront every slight or affront, and should seek to get along with their colleagues. Yet, while both of us might counsel keeping your head down to others, we find the injunction that one stay silent on the issues one cares most about for six years unbearable (Fogelman 1993; Stone 1993).

One of the many helpful readers of this essay also pointed out that generic advice fails to take into account the vast diversity among political science departments, rendering such advice less helpful. Departments have different expectations for service, teaching, and scholarship as well as different cultures and styles of governance. In a departmental culture that values collective decision making, a failure to participate and an undue deference to one's seniors may lead others to conclude that the new faculty member does not belong.

10. For a discussion of the chilly climate for women of color professors in the classroom, see Man Ling Lee (1997) and Monture-Okanee (1995).
11. Women professors who defy their students' gendered presumptions that they will always be giving and nurturing are harshly criticized in evaluations (Andersen and Miller 1997; Statham, Richardson, and Cook 1991).

12. For an excellent example of how identical behaviors in men and women are evaluated differently, see Josefowitz $(1983,60)$. Also see Hopkins (1996) for a discussion of Price Waterhouse v. Hopkins, 490 U.S. 228 (1989). Ann Hopkins was denied partnership at Price Waterhouse because, in part, her colleagues deemed her to be insufficiently feminine. See Martin (1980) for a discussion of the feminine/professional dichotomy in policing.

13. The conceptual problem of perceiving discrimination as affective (hating women) rather than cognitive (seeing women as less valuable than men) permeates contemporary judicial approaches to discrimination (Krieger 1995). Defining discrimination as the intentional acts of bigots eclipses the more subtle ways women and the work they do is devalued. See Schultz (1998) for a broader discussion of devaluation in the context of sexual harassment and Dalton $(1988,7)$ on conservatives and unconscious discrimination.

14. Mariah Burton Nelson, in her book The Stronger Women Get, the More Men Love Football $(1994,121)$ recounts how male bonding talk excludes women, even when women are better equipped then men to participate and eager to share their enthusiasm for sports. Nelson recounts how she and another man boarded a shuttle bus at the airport. The man began chatting to the driver (a stranger, but another man) about an important game, inquiring who won. Nelson tried to enter the conversation, saying "I was just at that game." Neither man could bring himself to ask her who won. Although she was a professional athlete, was knowledgeable about sports, and, had been at the game under discussion, she was not allowed to participate in their male- bonding conversation. Since they could not bring themselves to ask, she did not tell.

15. Affiliating with women's studies, or even doing research on women, is usually sufficient to get scholarship ejected from the category of political science. Women's studies and political science are often perceived as two separate entities rather than intersecting sets. Work can be one or the other, not both, and if you do work on women and politics, the women part trumps the politics part (Duquette 1996; Kelly, Williams, and Fisher 1994; Kenney 1995, 51-57).

16. Feldthusen called this "the right not to know." He wrote: "Men tend more than women to see events as isolated, individual episodes, and are reluctant to see patterns of behaviour explicable on the basis of sex. By this exercise of the right not to know, men distance themselves from the conduct of their brothers" $(1995,286)$

17. Linda Lucas (1990b) has great advice of what others can do to be supportive.

18. Schultz described how judges deny the cumulative effect of patterns of hostile behavior in hostile workplace sexual harassment claims. They examine each incident in isolation, and then deny that any alone rises to the level of actionable harm, a process Schultz labeled "disaggregation" $(1998,1720)$ 29). According to Schultz, gender harassment-the way women's competencies are repeatedly challenged and their contributions devalued in the workplace--should be considered as, if not more, harmful than the way women are often treated as objects of sexual desire (1762-69).

19. One reviewer wrote: "As for your concern about it being too pessimistic-I think the greater effect will be that women will be relieved to learn that others (of considerable merit) have faced the 'seemingly trivial daily experiences of oppression' and know it to be such."

\section{References}

Andersen, Kristi, and Elizabeth D. Miller. 1997. "Gender and Student Evaluations of Teaching." PS: Political Science and Politics 30(June): 216-19.

Baker, Ralph, and Fred Meyer. 1993. "Exploring the Litigation Potential for Chilly Climate Problems in Academia." Presented at the Annual Meeting of the American Political Science Association, Washington, DC.

Bateson, Mary Catherine. 1989. Composing a Life. New York: Atlantic Monthly Press.

Becker, Howard Saul. 1986. Writing for Social Scientists: How to Start and Finish Your Thesis, Book, or Article. Chicago: University of Chicago Press.

Bell, Derrick. 1992. Faces at the Bottom of the Well: The Permanence of Racism. New York: Basic Books.

Boice, Robert. 1992. The New Faculty Member: Supporting and Fostering Professional Development. San Francisco: Jossey-Bass.

Brintnall, Michael. 1992. "Affirmative Action: Women and Minorities in the Profession."
PS: Political Science and Politics 25(March): 105-10.

Bumiller, Kristin. 1987. The Civil Rights Society: The Social Construction of Victims. Baltimore: Johns Hopkins University Press.

Caplan, Paula J. 1994. Lifting a Ton of Feathers: A Woman's Guide to Surviving in the Academic World. Toronto: University of Toronto Press.

Chamallas, Martha. 1990. "Listening to Dr. Fiske: The Easy Case of Price Waterhouse v. Hopkins." Vermont Law Review 15(Summer): $89-124$.

_-. 1994. "Jean Jew's Case: Resisting Sexual Harassment in the Academy." Yale Joumal of Law and Feminism 6(Winter): 71-90.

The Chilly Climate Collective, eds. 1995. Breaking Anonymity: The Chilly Climate for Women Faculty. Waterloo, Ontario: Wilfred Laurier University Press.

Committee on the Status of Women in the Profession. 1992. "Improving the Status of Women in Political Science: A Final Report with Recommendations." PS: Political
Science and Politics 25(September): 54754.

Dalton, Clare. 1988. "The Political is Personal in Tenure Decisions." Harvard Law Record 86(8): 7-8.

Disch, Lisa, and Mary Jo Kane. 1996. "When a Looker is Really a Bitch: Lisa Olson, Sport, and the Heterosexual Matrix." Signs 21(Winter): 278-308.

Duquette, Cynthia. 1996. "Gender and Generations: Let's Talk." PS: Political Science and Politics 29(June): 181-84.

Feldthusen, Bruce. 1995. "Where the Boys Are." In Breaking Anonymity: The Chilly Climate for Women Faculty, ed. The Chilly Climate Collective. Waterloo, Ontario: Wilfred Laurier University Press.

Fisher, Bonnie S., Craig Cobane, Thomas M. Vander Ven, and Frances T. Cullen. 1998. "How Many Authors Does It Take to Publish an Article? Trends and Patterns in Political Science." PS: Political Science and Politics 31(December): 847-56.

Fiske, Susan T. 1993. "Social Cognition and 
Social Perception." Annual Review of Psychology 44:155-95.

Fogelman, Edwin. 1993. "Uncle Wuffle Redux." PS: Political Science and Politics 26(June): 171.

Frye, Marilyn. 1983. The Politics of Reality. Trumansburg, NY: The Crossing Press.

Greene, Linda S. 1997. "Tokens, Role Models, and Pedagogical Politics: Lamentations of an African American Female Law Professor." In Critical Race Feminism: A Reader, ed. Adrien Katherine Wing. New York: New York University Press.

Hall, Roberta M., and Bernice R. Sandler. 1986. The Campas Climate Revisited: Chilly For Women Faculty, Administrators and Graduate Students. Washington, DC: Project on the Status and Education of Women, Association of American Colleges.

Hesli, Vicki and Barbara Burrell. 1995. "Faculty Rank among Political Scientists and Reports on the Academic Environment: The Differential Impact of Gender on $\mathrm{Ob}$ served Patterns." PS: Political Science and Politics 28(March): 101-12.

Hopkins, Ann Branigar. 1996. So Ordered: Making Partner the Hard Way. Amherst: University of Massachusetts Press.

Josefowitz, Natasha. 1983. Paths to Power: A Woman's Guide from First Job to Top Executive. Reading, MA: Addison-Wesley.

Kanter, Rosabeth Moss. 1977. Men and Women of the Corporation. New York: Basic Books.

Kelly, Rita Mae, Linda M. Williams, and Kimberly Fisher. 1994. "Women and Politics: An Assessment of Its Role Within the Discipline of Political Science." Women and Politics 14(4): 3-18.

Kenney, Sally J. 1995. "Women, Feminism, Gender, and the Law: Ruminations of a Feminist Academic." Women and Politics 15(3): 43-69.

-. 1996a. "Gender, Women, Integration, and Political Institutions: Theory and Directions for Future Research." Political Research Quarterly 49(June): 445-66.
- 1996b. "Resources for Women Faculty." WCPS Quarterly: Newsletter of the Women's Caucus for Political Science 13(5): 7-8.

Kolodny, Annette. 1993. "Raising Standards While Lowering Anxieties: Rethinking the Promotion and Tenure Process." Concerns 23(Spring): $16-40$.

Krieger, Linda Hamilton. 1995. "The Content of Our Categories: A Cognitive Bias Approach to Discrimination and Equal Employment Opportunity." Stanford Law Review 47(July): 1161-248.

Leap, Terry L. 1995. Tenure, Discrimination, and the Courts. Ithaca: Cornell University Press.

Limbert, Claudia A. 1995. "Chrysalis, A Peer Mentoring Group for Faculty and Staff Women." National Women's Studies Association Journal 7(Summer): 86-99.

Lucas, Linda A. 1990a. "77 Things You Can Say or Do for Your Woman Friend Who Has Been Denied Tenure." Presented at the Mary Ingraham Bunting Institute Colloquium Series, Boston.

-. 1990b. "Confronting the Wizard of Oz or an Introduction to Administrative/Legal Process." Presented at the Mary Ingraham Bunting Institute Colloquium Series, Boston.

Man Ling Lee, Theresa. 1997. "Teaching the 'Canon' from the Perspective of a Woman of Color." PS: Political Science and Politics 30(March): 7-9.

Martin, Susan Ehrlich. 1980. Breaking and Entering: Police-Women on Patrol. Berkeley: University of California Press.

Mathews, Anne. 1992. "Rage in a Tenured Position," The New York Times, November 8 .

McIntyre, Sheila. 1995. "Gender Bias within the Law School: 'The Memo' and Its Impact." In Breaking Anonymity: The Chilly Climate for Women Faculty, ed. The Chilly Climate Collective. Waterloo, Ontario: Wilfrid Laurier University Press.

Monture-Okanee, Patricia A. 1995. "Introduction-Surviving the Contradictions: Personal Notes on Academia." In Breaking
Anonymity: The Chilly Climate for Women Faculty, ed. The Chilly Climate Collective. Waterloo, Ontario: Wilfred Laurier University Press.

Nelson, Mariah Burton. 1994. The Stronger Women Get, the More Men Love Football: Sexism and the American Culture of Sports. New York: Harcourt Brace.

Ruddick, Sara, and Pamela Daniels, eds. 1977. Working it Out: 23 Women Writers, Artists, Scientists, and Scholars Talk about Their Lives and Work. New York: Pantheon.

Russell, Jennifer M. 1997. "On Being a Gorilla in Your Midst, of the Life of One Blackwoman in the Legal Academy." In Critical Race Feminism: A Reader, ed. Adrien Katherine Wing. New York: New York University Press.

Sarkees, Meredith Reid, and Nancy McGlen. 1992. "Confronting Barriers: The Status of Women in Political Science." Women \& Politics 12(4): 43-86.

Schultz, Vicki. 1998. "Reconceptualizing Scxual Harassment." Yale Law Journal 107(April): 1683-1805.

Statham, Anne, Laurel Richardson, and Judith Cook. 1991. Gender and University Teaching. Albany, NY: State University of New York Press.

Sterett, Susan. 1994. "Daydreaming a Woman's Life." Studies in Law, Politics, and Society 14: 69-88.

Stone, Alec. 1993. "Response to "Uncle Wuffle's Advice to Assistant Professors'." PS: Political Science and Politics 26(June): $170-71$.

Toth, Emily. 1997. Ms. Mentor's Impeccable Advice for Women in Academia. Philadelphia: University of Pennsylvania Press.

Whicker, Marcia Lynn, Jennic Jacobs Kronenfeld, and Ruth Ann Strickland. 1993. Getting Tenure. Newbury Park, CA: Sage.

Wuffle, A. 1993. "Uncle Wuffle's Advice to the Assistant Professor." PS: Political Science and Politics 26(March): 89-9). 